\title{
EVALUASI KESESUAIAN LAHAN UNTUK PENGEMBANGAN KELAPA BABASAL (Cocos nucifera) DI KECAMATAN BATUI KABUPATEN BANGGAI
}

\author{
Sariani $^{1}$, Herwin Yatim ${ }^{1}$, Hidaya A.M Katili ${ }^{*}$ \\ ${ }^{1}$ Program Studi Agroteknologi, Fakultas Pertanian, Universitas Tompotika Luwuk \\ Banggai, Indonesia. \\ Jalan Dewi Sartika, Kelurahan Karaton Luwuk, Kabupaten Banggai, Sulawesi Tengah \\ Indonesia No. 65 Telp./Fax.(0461)324027 \\ E-Mail: hidayat.katili11@gmail.com
}

\begin{abstract}
ABSTRAK
Evaluasi Kesesuaian Lahan Untuk Pengembangan Kelapa Babasal (Cocos nucifera) Di Kecamatan Batui Kabupaten Banggai. Melihat prospek cerah tanaman kelapa Babasal dengan potensi lahan yang tersedia di Kecamatan Batui Kabupaten Banggai, maka perlu adanya evaluasi lahan untuk pengembangan tanaman kelapa Babasal. Penelitian ini bertujuan untuk mengetahui kesesuaian lahan dan faktor pembatas serta upaya pengolahan dalam pengembangan tanaman Kelapa Babasal (Cocos nucifera) di Kecamatan Batui. Penelitian ini berlansung sejak Bulan Juli sampai September 2020, dengan menggunakan metode pendekatan parametrik indeks lahan akar kuadrat Khiddir serta ditabulasikan kedalam Satuan Peta Lahan (SPL). Hasil penelitian menunjukkan bahwa kelas kesesuaian lahan aktual di Kecamatan Batui yaitu SPL 1, SPL 2, SPL 3, SPL 4, SPL 5, SPL 6, SPL 7, SPL 8, SPL 9 yaitu S3 (marginal) adapun faktor pembatasnya yaitu tekstur, lereng, bahaya banjir dan N-total. Selanjutnya untuk upaya perbaikannya adalah pengelolaan tingkat sedang sampai tinggi dengan melakukan pemupukan, pembuatan teras, penanaman sejajar kontur, penanaman penutup tanah, pembuatan tanggul dan pembuatan saluran drainase. Arahan pengembangan kelapa Babasal (Cocos nucifera) Kecamatan Batui dengan kesesuaian potensial yaitu, SPL 3 tergolong kriteria S1 (sangat sesuai) dengan luas 3.731,16 ha. Selanjutnya pada SPL 1, SPL 2, SPL 4, SPL 5, SPL 6, SPL 7, SPL 8 dan SPL 9 berkriteria S3 (marginal) dengan luas 21288,21 ha. Adapun faktor pembatas kesesuaian lahan potensial Kecamatan Batui adalah kandungan Tekstur yang berkriteria agak kasar dan tidak dapat dilakukan perbaikan.
\end{abstract}

Kata kunci : Evaluasi, lahan, Kelapa Babasal

\begin{abstract}
Evaluation of Land Suitability for Development of Babasal Coconut (Cocos nucifera) in Batui District, Banggai Regency. Seeing the bright prospect of the Babasal coconut plant with the potential land available in Batui District, Banggai Regency, it is necessary to evaluate the land for the development of the Babasal coconut plant. This study aims to determine land suitability and limiting factors as well as processing efforts in the development of Babasal Coconut (Cocos nucifera) in Batui District. This research took place from July to September 2020, using the parametric approach method of Khiddir's square root land index and tabulated into the Land Map Unit (SPL). The results showed that the actual land suitability classes in Batui District were SPL 1, SPL 2, SPL 3, SPL 4, SPL 5, SPL 6, SPL 7, SPL 8, SPL 9, namely S3 (marginal) while the limiting factors were texture, slope. , flood hazard and $N$-total. Furthermore, for improvement efforts are moderate to high level management by fertilizing, making terraces, planting parallel to contours, planting ground cover, constructing embankments and constructing drainage channels. The direction for the development of Babasal coconut (Cocos nucifera) in Batui District with potential suitability, namely, SPL 3 is classified as S1 criteria (very suitable) with an area of 3,731.16 ha. Furthermore, at SPL 1, SPL 2, SPL 4, SPL 5, SPL 6, SPL 7, SPL 8 and SPL 9 with S3 criteria (marginal) with an area of 21288.21 ha. The limiting factor for the potential land suitability of Batui District is the texture content which has a slightly rough criteria and cannot be repaired.
\end{abstract}

Key words : Babasal Coconut, Evaluation, land. 


\section{PENDAHULUAN}

Provinsi Sulawesi Tengah merupakan salah satu daerah sentra pengembangan tanaman kelapa di Indonesia. Penyebaran tanaman kelapa ini meliputi Kabupaten Banggai. Dimana daerah tersebut memiliki potensi yang besar untuk pengembangan kelapa, Berdasarkan data statistik, luas areal kelapa di Sulawesi Tengah 176.714 ha, dan 54.267 ha $(30,80 \%)$ terdapat di Kabupaten Banggai (Tenda, 2017).

Balai Penelitian Tanaman Palma melakukan eksplorasi di Kabupaten Banggai. Hasil eksplorasi adalah diperoleh aksesi kelapa yang memiliki potensi produksi buah tinggi, oleh masyarakat setempat dikenal dengan kelapa kapal (kelapa Babasal). Sejak tahun 2014 tim peneliti Balai Penelitian Tanaman Palma (Balit Palma) melakukan observasi untuk mengetahui pembudidayaan kelapa tersebut. Hasil penelitian menunjukkan bahwa kelapa kapal (Babasal) telah dikembangkan oleh masyarakat di wilayah kabupaten Banggai sejak puluhan tahun yang lalu.

Berdasarkan Data perkebunan besar yang dikumpulkan oleh Badan Pusat Statistik setiap bulan secara lengkap dengan sistem surat pos, luas area perkebunan kelapa Kabupaten Banggai 54.649 ha dengan produksi mencapai 48.132 ton (BPS Banggai, 2019). Maka untuk mempertahankan dan meningkatkan produksi tanaman ini, harus ada perencanaan yang matang dilihat pada karakter dan kesesuaian lahan yang sesuai dengan tata cara yang baik, karena dalam hal ini lahan dapat berpengaruh terhadap pertumbuhan dan produksi dari tanaman yang ada di wilayah tertentu.

Kecamatan Batui sebagai salah satu wilayah yang secara fisik lahannya dianggap memiliki potensi pengembangan perkebunan kelapa Babasal. namun dalam penentu pengembangan komoditas ini yaitu faktor kesesuaian lahannya. Damopolii (2014) menyatakan bahwa kesesuaian lahan merupakan tingkat kecocokan sebidang lahan untuk penggunaan tanaman dan komoditi tertentu. Kesesuaian lahan dipengaruhi oleh faktor pembatas yaitu kualitas/ karakteristik lahan meliputi iklim, topografi, sifat fisik dan kesuburan tanah, serta sodisitas (Nurdin, 2010). Melihat Prospek cerah tanaman ini dan potensi lahan yang tersedia, maka dilakukan sebuah kajian tentang Evaluasi Kesesuaian Lahan dalam upaya Pengembangan Kelapa Babasal di Kabupaten Banggai.

\section{METODA PENELITIAN}

\subsection{Tempat dan Waktu}

Penelitian dilaksanakan di Kecamatan Batui Kabupaten Banggai pada Bulan Juli sampai September 2020.

\subsection{Bahan dan Alat}

Bahan yang diteliti adalah lahan pertanian berupa tanah yang ada di kawasan Batui. Selanjutnya, Alat yang digunakan terdiri dari pisau, buku warna tanah (munsell soil colour chart), blangko pengamatan profil tanah, meteran, bor tanah, pacul, sekop, parang, altimeter, GPS (Global Positioning System), kantong plastik, karet gelang, kertas label dan spidol F.

\subsection{Penetapan Lokasi Sampel}

Lokasi ditetapkan berdasarkan peta satuan lahan pada beberapa titik yang dinilai dapat mewakili lahan keseluruhan dengan membagi beberapa kelompok (Bawah Lereng, Tengah Lereng dan Lereng Atas), dengan membuat profil tanah pada masing-masing titik pengambilan sampel tanah (Siswanto 2006). Penetapan lokasi tersebut ditetapkan secara komposit dari bawah lereng secara vertikal dengan titik titik yang telah ditentukan dari satuan lahan. 


\subsection{Parameter Pengamatan}

Berdasarkan karakteristik lahan yang telah disebutkan maka parameter yang diukur dalam penelitian ini adalah :

Sifat Fisik : Temperatur rata-rata $\left({ }^{\circ} \mathrm{C}\right)$, Curah Hujan ( $\mathrm{mm} /$ tahun ), Drainase, Tekstur, Kedalam tanah $(\mathrm{cm})$, Lereng (\%),Genangan. Serta sifat Kimia : KTK (me/100 g), pH $\mathrm{H}_{2} \mathrm{O}$, Kejenuhan basa (\%),C-organik (\%),N total (\%),P2O5 $(\mathrm{mg} / 100 \mathrm{~g}), \mathrm{K} 2 \mathrm{O}(\mathrm{mg} / 100 \mathrm{~g})$.

\subsection{Analisis dan Interpretasi Data}

Data yang diperoleh, diolah dan disajikan dalam bentuk tabel dan gambar. Selanjutnya, data tersebut dianalisis secara deskriptif dan kuantitatif serta diinterpretasi sesuai dengan tujuan penelitian. Khusus dalam penelitian potensi lahan dilakukan analisis kesesuaian lahan tersebut berdasarkan kerangka kerja evaluasi lahan (FAO, 1976) dan kriteria kesesuaian lahan (Djenudin et al, 2011) dengan mempertimbangkan keadaan aktual di lapang.

\subsection{Penentuan Kelas Kesesuaian Lahan}

Kelas Kesesuaian Lahan ditentukan berdasarkan nilai Indeks Lahan. Indeks Lahan ditetapkan berdasarkan kualitas lahan yang dihitung dengan menggunakan metode indeks lahan akar kuadrat (Khiddir, 1986).

$$
\mathrm{I}=\mathrm{Rmin} x \sqrt{\frac{\mathrm{A}}{100}} \quad \boldsymbol{x} \frac{\mathrm{B}}{100} \quad x \quad \ldots
$$

dimana :

$$
\begin{array}{ll}
\mathrm{I} & =\text { Indeks Lahan } \\
\mathrm{Rmin} & =\text { Rating minimum kualitas lahan } \\
\mathrm{A}, \mathrm{B} & =\text { Rating kualitas lahan lainnya selain rating kualitas lahan minimum }
\end{array}
$$

Nilai Indeks Lahan yang diperoleh untuk menentukan Kelas Kesesuaian disesuaikan dengan Tabel 1 dibawah Lahan

Tabel 1. Kelas Kesesuaian Lahan Berdasarkan Indeks lahan

\begin{tabular}{ccc}
\hline Indeks Lahan & Kelas Kesesuaian Lahan & Keterangan \\
\hline $100-75$ & S1 & Sangat Sesuai \\
$75-50$ & S2 & Agak Sesuai \\
$50-25$ & S3 & Sesuai Marginal \\
$0-25$ & $\mathrm{~N}$ & Tidak Sesuai \\
\hline
\end{tabular}

Sumber : Ritung et al (2011)

\subsection{Analisis Sistem Informasi Geografis}

Secara spasial, melalui teknik sistem informasi geografis, komponen data tanah, kualitas tanah, pengelolaan tanah, dan ancaman erosi pada tiap unit lahan dijadikan atribut unit lahan ini, kemudian ditumpangtindihkan (overlayed) dengan syarat tumbuh (crop requirement) atau kriteria kesesuaian lahan tanaman padi. Hasil dari overlayed tersebut adalah peta kesesuaian lahan.
Prosedur Pembuatan Peta

Untuk membuat peta satuan lahan dibutuhkan beberapa jenis peta yaitu peta administrasi, peta lereng, peta penggunaan lahan dalam format digital dengan bentuk data spasial. Pengumpulan data spasial dan data atribut serta persiapan pemasukan data menempati posisi kunci dalam pekerjaan ini. Hal ini 
disebabkan hasil akhir selain dipengaruhi kualitas data, juga sangat ditentukan oleh kombinasi analisis dan kombinasi dalam perangkat lunak/keras dengan kemampuan operator SIG. Tahap pembuatan peta satuan lahan adalah sebagai berikut :

1. Pertama buka jendela Arc GIS 10.4.1

2. Kita memasukkan peta-peta yang akan digunakan, kemudian di samakan titik koordinat dengan hasil lapang

3. Setelah semua peta dan titik koordinatnya sudah sama, maka peta-peta tadi kemudian ditumpangtindihkan menjadi satu peta.

4. Setelah peta tersebut ditumpangtindih selanjutnya dilakukan digitasi lahan untuk mendapatkan satuan-satuan lahan.

5. Setelah digitasi selesai, maka selanjutnya yang dilakukan adalah pemberian nomor satuan lahan. Nomor satuan lahan ini yang menjadi dasar kita untuk menentukan tingkat kesesuaian lahan.

Tahap Pembuatan Peta Kesesuaian Lahan

Untuk membuat peta kesesuaian dibutuhkan data-data yang akan dimasukkan dalam peta. Data-data tersebut adalah data-data sekunder yang sesuai dengan kriteria kesesuaian lahan. Tahap pembuatan peta kesesuaian lahan adalah sebagai berikut :

1. Hasil digitasi lahan sebelumnya yang telah dibuat selanjutnya di join atau dipadankan dengan data kesesuaian lahan yang telah disiapkan.

2. Setelah dipastikan data semua sudah dimasukkan kedalam peta kemudian dilakukan pengevaluasian kelas kesesuaian lahan.

3. Hasil evaluasi tersebut kemudian di buat peta kesesuaian lahan

\section{HASIL PENELITIAN DAN PEMBAHASAN}

\subsection{Kesesuaian Lahan Aktual Kelapa Babasal Kecamatan Batui}

Kualitas Lahan adalah sifat-sifat atau attribute yang bersifat kompleks dari suatu bidang lahan. Setiap kualitas lahan mempunyai keragaan (performance) yang berpengaruh terhadap kesesuaiannya bagi penggunaan tertentu. Kualitas lahan ada yang diestimasi atau diukur secara langsung dilapangan tetapi pada umumnya ditetapkan dari pengertian karakteristik lahan (FAO, 1976).

Hasil yang di peroleh, kualitas lahan lokasi penelitian dikecamatan Batui pada SPL 1, SPL 8 dan SPL 9 diperoleh kelas kesesuaian lahan aktual S3s (marginal) dengan faktor pembatas yaitu tekstur (s). Selanjutnya pada kesesuaian lahan aktual SPL 2, SPL 5 dan SPL 6 diperoleh hasil S3ts (marginal) faktor pembatasnya yaitu kemiringan lereng (t) dan tekstur (s). Sedang pada keseuasian lahan aktual SPL 3, diperoleh faktor pembatas S3na yaitu kandungan N-total (s) rendah. Serta SPL 4 mempunyai kelas kesesuaian lahan aktual (margianal) S3ws dengan faktor pembatas bahaya banjir (w), tekstur (s). Serta SPL 7 telah diperoleh hasil kelas kesesuaian lahannya (marginal) S3tsna yang berfaktor pembatas kemiringan lereng (t), tekstur (s) rendah dan kandungan $\mathrm{N}$-total (na) rendah.

Penentuan Kelas Kesesuaian Lahan (KKL) didasarkan pada metode parametrik Sys et al. (1991) dengan menggunakan beberapa faktor yang dapat mempengaruhi karakteristik sebuah lahan. Faktor-faktor tersebut yaitu Iklim (c), Topografi (t), Bahaya Erosi (eh), Kebasahan (w), Sifat Fisik Tanah (s), 
Sifat Kesuburan Tanah (f) dan hara tersedia (na). Selanjunya Ritung et al,. (2011) menyatakan kelas kesesuaian lahan aktual menyatakan kesesuaian lahan berdasarkan data hasil survei tanah atau sumberdaya lahan yang belum mempertimbangkan masukan-masukan yang diperlukan untuk mengatasi kendala atau faktor pembatas hubungannya dengan persyaratan tumbuh tanaman.

\subsection{Upaya Perbaiakn Lahan Kelapa Babasal Kecamatan Batui}

Kesesuaian lahan yang ada di daerah penelitian dari penilaian masing-masing contoh profil tanah tersebut diperoleh beberapa faktor pembatas yang dapat memghambat poses pertumbuhan tanaman Kelapa Babasal. Dengan demikian perlu adanya upaya perbaikan lahan sehingga dapat meningkatkan kelas kesesuain lahan.
Upaya perbaikan lahan dilakukan dengan melihat kesesuaian lahan potensial di daerah penelitian dalam hal ini diwakili oleh sembilan contoh profil tanah yang telah disebutkan sebelumnya. Potensi tersebut dinilai dari faktor-faktor pembatas yang dapat dilakukan perbaikan seperti pada lokasi penelitian ini diperoleh faktor pembatas yaitu : Lereng (t); Bahaya Banjir (w); N-total (na) serta Tekstur (s).

\subsection{Kesesuaian Lahan Potensial Kelapa Babasal Kecamatan Batui \\ Setelah dianalisis faktor} pembatasnya dengan berdasarkan upaya perbaikan maka telah diperoleh kesesuaian lahan potensial pada lokasi SPL 1, SPL 2, SPL 4, SPL 5, SPL 6, SPL 7, SPL 8 dan SPL 9 S3s (marginal) hal ini dikarenakan tekstur tidak dapat dilakukan perbaiakan. Serta pada SPL 3 telah diperoleh hasil kelas kesesuaian lahan potensial (S1) sangat sesuai. Untuk lebih jelasnya perhatikan tabel dibawah ini :

Tabel 2. Penentuan Kriteria Kelas Kesesuaian Lahan Tanaman Kelapa Babasal Kecamatan Batui Kabupaten Banggai

\begin{tabular}{|c|c|c|c|c|c|c|}
\hline Profil & $\begin{array}{l}\text { Lahan } \\
\text { Aktual }\end{array}$ & $\begin{array}{c}\text { Faktor } \\
\text { Pembatas }\end{array}$ & Upaya Perbaikan & $\begin{array}{c}\text { Lahan } \\
\text { Potensial }\end{array}$ & Kriteria & $\begin{array}{c}\text { Luas } \\
\text { (ha) }\end{array}$ \\
\hline SPL 1 & S3s & tekstur & tidak dapat dilakukan & S3s & marginal & 1229,35 \\
\hline SPL 2 & S3ts & $\begin{array}{l}\text { Lereng } \\
\text { tekstur }\end{array}$ & $\begin{array}{c}\text { pembuatan teras, penanaman sejajar kontur, } \\
\text { penanaman tanaman penutup tanah dengan } \\
\text { tingkat pengelolaan yang tinggi. } \\
\text { tidak dapat dilakukan }\end{array}$ & S3s & marginal & 575,14 \\
\hline SPL 3 & S3na & $\mathrm{N}$-total & melakukan pemupukan & S1 & $\begin{array}{l}\text { Sangat } \\
\text { Sesuai }\end{array}$ & 3731,16 \\
\hline SPL 4 & S3ws & $\begin{array}{l}\text { Bahaya } \\
\text { Banjir } \\
\text { tekstur }\end{array}$ & $\begin{array}{c}\text { Pembuatan tanggul penahan banjir dan } \\
\text { pembuatan saluran drainase untuk } \\
\text { mempercepat pembuangan air } \\
\text { tidak dapat dilakukan }\end{array}$ & S3s & marginal & 2661,75 \\
\hline SPL 5 & S3ts & $\begin{array}{l}\text { Lereng } \\
\text { tekstur }\end{array}$ & $\begin{array}{l}\text { pembuatan teras, penanaman sejajar kontur, } \\
\text { penanaman tanaman penutup tanah dengan } \\
\text { tingkat pengelolaan yang tinggi. } \\
\text { tidak dapat dilakukan }\end{array}$ & S3s & marginal & 5060,65 \\
\hline SPL 6 & S3ts & $\begin{array}{l}\text { Lereng } \\
\text { tekstur }\end{array}$ & $\begin{array}{l}\text { pembuatan teras, penanaman sejajar kontur, } \\
\text { penanaman tanaman penutup tanah dengan } \\
\text { tingkat pengelolaan yang tinggi. } \\
\text { tidak dapat dilakukan } \\
\end{array}$ & S3s & marginal & 9714,88 \\
\hline SPL 7 & S3tsna & $\begin{array}{l}\text { Lereng } \\
\text { tekstur } \\
\text { N-total }\end{array}$ & $\begin{array}{c}\text { pembuatan teras, penanaman sejajar kontur, } \\
\text { penanaman tanaman penutup tanah dengan } \\
\text { tingkat pengelolaan yang tinggi. } \\
\text { tidak dapat dilakukan } \\
\text { melakukan pemupukan } \\
\end{array}$ & S3s & marginal & 1481,13 \\
\hline SPL 8 & S3s & tekstur & tidak dapat dilakukan & S3s & marginal & 415,26 \\
\hline \multirow[t]{2}{*}{ SPL 9} & S3s & tekstur & tidak dapat dilakukan & S3s & marginal & 147,05 \\
\hline & & & Total Luas Lahan & & & $25.016,39$ \\
\hline
\end{tabular}

Keterangan ; tekstur(s); lereng(t); hara tersedia(na); bahaya banjir(w). 
Berdasarkan hasil pengamatan di lapangan dan ditunjang dengan data analisis laboratorium, hasil pemadanan antara karakteristik lahan dan persyaratan tumbuh tanaman, penilaian kesesuaian lahan dengan metode yang digunakan menunjukkan adanya variasi kesesuaian lahan untuk tanaman Kelapa. Sistem kriteria Sys semua lahan dapat ditanami tanaman kelapa, namun pada kelas yang berbeda, yakni kelas S3 (sesuai marginal) dan kelas S1 (sangat sesuai). dari hasil pencocokan data karakteristik tanah dan tanaman maka diperoleh kelas kesesuaian lahan aktual pada lokasi penelitian SPL 1, SPL 2, SPL 3, SPL 4, SPL 5, SPL 6, SPL 7, SPL 8, serta SPL 9 adalah S3(t, s, w, na) dan kelas kesesuaian lahan potensial yang diperoleh pada SPL 3 yaitu Sangat sesuai (S1) dengan luas 3731,16 Ha. Selanjutnya pada SPL 1, SPL 2, SPL 4, SPL 5, SPL 6, SPL 7, SPL 8, serta SPL 9 yaitu (S3) sesuai marginal dengan luas lahan $(21.285,23 \mathrm{Ha})$. Penyebab lahan sesuai marginal ini karena adanya faktor pembatas tekstur secara permanen yang tidak dapat di lakukan pengolahan (Suriadukusumah et al., 2010).

Rayes (2007) menyatakan bahwa dalam evaluasi lahan, karakteristik lahan berupa tekstur jenis usaha perbaikan tidak dapat dilakukan. Selanjutnya Mubekti (2012) menyatakan bahwa pada kesesuaian potensial, Kelas lahan tidak bisa ditingkatkan menjadi kelas sesuai marjinal pada kesesuaian potensial dikarenakan faktor pembatas lahan yang berat dan pada umumnya tidak bisa diperbaiki seperti tekstur (s). Sedangkan tekstur tanah sangat peran penting terhadap akar tanaman, apabila suatu lahan tekstur berkadar minimal maka akan mempersulit akar tanaman untuk berpenetrasi dan tanah semakin tidak porus (Syofiani et al., 2020).

Selanjutnya Ardianto dan Al Iksan (2015) Kemiringan lereng dan panjang lereng memberikan dampak terhadap laju aliran permukaan yang membawa lapisan tanah atas beserta unsur hara dari tempat satu ke tempat lainnya yang lebih rendah. Sesuai dengan yang di nyatakan Dumipto et al. (2019) dimana nilai kemiringan lereng yang besar akan mengakibatkan tanah menjadi mudah tererosi atau kehilangan. selanjutnya menurut Martono (2004), lereng yang semakin curam dan semakin panjang akan meningkatkan kecepatan aliran permukaan dan volume air permukaan semakin besar, sehingga benda yang bisa diangkut akan lebih banyak.dan pada prisipnya akan merugikan para petani khususnya budidaya kelapa Babasal. Selanjutnya perbaikan yang dapat dilakukan pada karakteristik lereng adalah dengan melakukan kegiatan teknik konservasi tanah seperti Countour Strip Cropping (Yanti et al., 2015).

\subsection{Arahan Alokasi Lahan untuk Pengembangan Kelapa Babasal Kecamatan Batui Kabupaten Banggai}

Alokasi lahan untuk komoditas tanaman kelapa babasal dilakukan untuk seluruh wilayah Kecamatan Batui yang terletak di area potensial. Areal potensial untuk pengembangan komoditas tanaman Kelapa Babasal tersebut dilihat berdasarkan peta lahan potensial yang ada. Selanjutnya hasil kesesuaian lahan tersebut ditabulasikan dalam bentuk peta potensi pengembangan kelapa Babasal (Gambar 1.).

Berdasarkan peta Penggunaan Lahan dan Pola Ruang Kabupaten Banggai, lokasi penelitian yang diarahkan masuk dalam wilayah Ladang, kebun campuran, Kebun kelapa, Hutan (bukan hutan lindung), Alang-alang serta APL (Katili, 2020). Artinya untuk prospek pengembangan tanaman Kelapa Babasal di kecamatan Batui pada wilayah SPL 1, SPL 2, SPL 4, SPL 5, SPL 6, SPL 7, SPL 8, dan SPL 9 layak untuk di kembangkan 
walaupun terdapat faktor pembatas yang akan mempengaruhi pertumbuhan komoditi tersebut serta khusus pada wilayah SPL 3 sangat sesuai/ cocok untuk mengembangkan tanaman kelapa Babasal. Jika terdapat areal yang memiliki kelas kesesuaian lahan serta nilai yang sama maka akan dilihat berdasarkan kebijakan prioritas pengembangan komoditas daerah, baik ditingkat Kabupaten, Provinsi, maupun tingkat Nasional dengan mempertimbangkan luas eksisting komoditas utama yang ada pada areal tersebut. Secara spasial area pengembangan komoditas kelapa babasal ini ditampilkan pada gambar 3 diatas, yang secara keseluruhan sebaran wilayah yang di arahkan untuk pengembangannya.

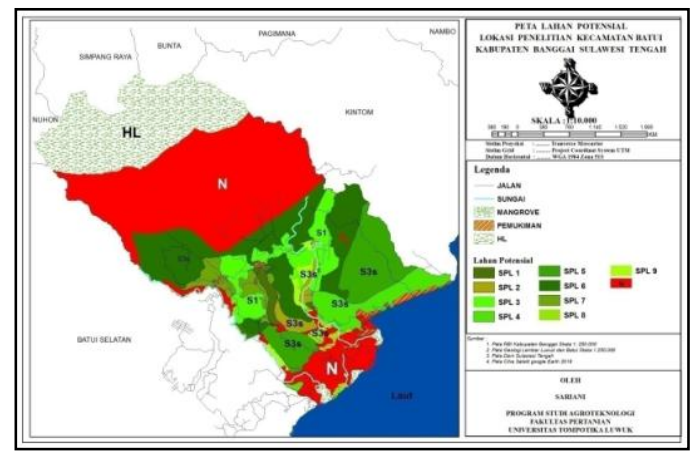

Gambar 1. Peta Potensial Alokasi Pengembangan Kelapa Babasal di Kecamatan Batui

\section{KESIMPULAN}

Berdasarkan penjelasan dari hasil penelitian evaluasi kesesuaian lahan terhadap pengembangan tanaman Kelapa Babasal maka dapat disimpulkan bahwa.

Kelas kesesuaian lahan untuk tanaman Kelapa Babasal Kecamatan Batui yaitu (S3) sesuai marginal dan (S1) sangat sesuai. Dengan sebaran satuan lahan kelas S3 yaitu pada SPL 1, SPL 2, SPL 4, SPL 5, SPL 6, SPL 7, SPL 8 dan SPL 9 dengan luas lahan $(21.285,23 \mathrm{Ha})$. Sedangkan untuk kelas S1 tersebar pada satuan lahan pada SPL 3 dengan luas lahan $(3.731,16 \mathrm{Ha})$.

Selanjutnya Pada Kelas Kesesuaian lahan Aktual Lahan memiliki faktor pembatas pada wilayah-wilayah tertentu yaitu lereng $(\mathrm{t})$, tekstur ( $\mathrm{s}$ ), bahaya banjir (w) dan N-total (na). Akan tetapi berdasarkan upaya perbaikan maka diperoleh kesesuaian lahan potensial S3 (marginal) dengan faktor pembatas tekstur (s). hal ini dikarenakan tekstur tidak dapat dilakukan perbaiakan. selanjutnya kelas kesesuaian lahan S1 yang sangat sesuai terdapat diwilayah ini pula. sehinggahnya, untuk prospek kedepannya tanaman kelapa Babasal sangat sesuai/ cocok untuk dikengembangkan pada wilayah Kecamatan Batui Kabupaten Banggai.

\section{DAFTAR PUSTAKA}

Ardianto K. \& Al Iksan A. (2017). Pengukuran Dan Pendugaan Erosi Pada Lahan Perkebunan Kelapa Sawit Dengan Kemiringan Berbeda. Jurnal Online Mahasiswa (JOM) Riau 4 (1): 1-15

BPS Banggai (2019). Banggai Dalam Angka, Badan Pusat Statistik Kabupaten Banggai.

Damopolii W. (2014). Penilaian Kesesuaian Lahan Tanaman 
Asparagus Sayur (Asparagus officinalis L.) Di desa Mooat Kabupaten Bolaang Mongondow Timur. Skripsi Fakultas Pertanian. Universitas Negeri Gorontalo

Djaenudin, D., Marwan, H., Subagjo, H., dan A. Hidayat. (2011). Petunjuk Teknis Evaluasi Lahan Untuk Komoditas Pertanian. Balai Besar Litbang Sumberdaya Lahan Pertanian, Badan Litbang Pertanian, Bogor.

Dumipto PK,. Rayes ML, \& Cristanti A (2019). Evaluasi Kesesuaian Lahan Untuk Tanaman Tebu Pada Lahan Karst Formasi Wonosari (TMWL) Kecamatan Gedangan Kabupaten Malang. Jurnal Tanah dan Sumberdaya Lahan 6 (2): 13611374

FAO. (1976). A Framework for Land Evaluation. Soil Resources Management and Conservation Service Land and Water Development Division. FAO Soil Bulletin No. 32. FAO-UNO, Rome

Katili H.A (2020). Food Crop Land Use Planning in Banggai Regency. Jurnal Pertanian Tropik. 7 (1) ; 1224

Martono. (2004). Pengaruh Intensitas Hujan dan Kemiringan Lereng terhadap Laju Kehilangan Tanah pada Tanah Regosol Kelabu. Tesis. Univesitas Diponegoro. Semarang

Mubekti (2012). Evaluasi Karakterisasi dan Kesesuaian Lahan Untuk Komoditas Unggulan Perkebunan : Studi Kasus Kabupaten Kampar. Jurnal Teknik Lingungan 13 (1): 37-46

Nurdin (2011) Development and Rainfed Paddy Soils Potency Derived From Lacustrine Material in Paguyaman,
Gorontalo. Journal of Tropical Soils. 16 (3) ; 267-278

Rayes, M.L., (2007). Metode Inventarisasi Sumber Daya Lahan. Andi. Yogyakarta

Ritung, S., K. Nugroho, A. Mulyani, dan E. Suryani. (2011). Petunjuk Teknis Evaluasi Lahan Untuk Komoditas Pertanian (Edisi Revisi). Balai Besar Penelitian dan Pengembangan Sumberdaya Lahan Pertanian, Badan Penelitian dan Pengembangan Pertanian, Bogor.

Suriadikusumah A. \& Pratama A. (2010). Penetapan Kelembaban, Tekstur Tanah dan Kesesuaian Lahan untuk Tanaman Kina (Chinchonna spp.) Di Sub-DAS Cikapundung Hulu Melalui Citra Satelit Landsat-TM Image. Jurnal Agrikultura. 21(1) ; 85-92

Siswanto, (2006). Evaluasi Sumber Daya Lahan. Surabaya : UPN Press

Syofiani, R., Putri, S.D \& Karjunita, N. (2020). Karakteristik Sifat Tanah Sebagai Faktor Penentu Potensi Pertanian Di Nagari Silokek Kawasan Geopark Nasional. Jurnal Agrium 17(1) ; 1-6

Sys, C. E. Van Ranst. J. Debaveye dan F. Beernaert. (1991). Land evaluation part I: principles in land evaluation and crop calculations. Part II: methods in land evaluation. Brussel-Belgium: Agricultural publication no. 7

Yanti, D. Arlius, F. Nurmansyah, W. (2015) Analisis Kesesuaian Lahan Untuk Tanaman Perkebunan Di Kecamatan Bungus Teluk Kabung Kota Padang. Jurnal Teknologi Pertanian Andalas. 19 (1): 15-26 